\section{Family Tradition}

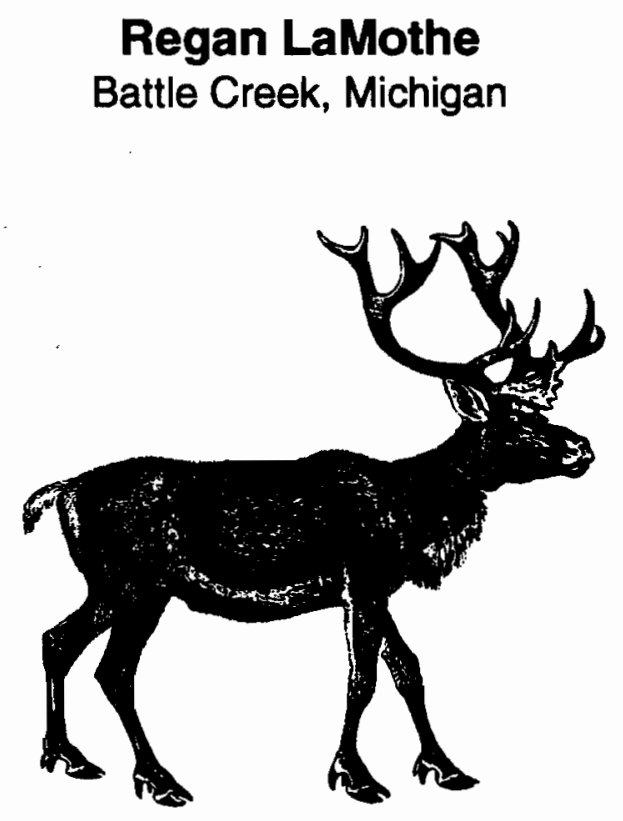

About 12 years ago, in my second year of college, a friend of mine and I decided to go out to a nearby DNR wetlands preserve and hunt for a few hours. It was late afternoon, a picture perfect Michigan afternoon in November. The air was crisp and scrubbed with a heady pine scent. Both Dan and I agreed that it wouldn't be so bad if we never shot a thing, it was just glorious to be out on such a fine day.

Dan had hunted since he was a small boy. His father had been a dedicated hunter and was determined Dan would be too. Dan never talked about the hunting experiences he shared with his father, and I found it odd that he had never once shot an animal. Occasionally I would toy with the idea of asking why, but I began to think that he did it almost as a courtesy to me. I had never hunted before and showed no interest in anything connected with hunting. I didn't even own the gun I carried; it had been Dan's as a boy. But I enjoyed these nature walks and the weight of the old shotgun balanced in the crook of my arm made me feel as if I had a more macho reason to be in the woods than just to gawk at wildlife.

As we walked through the fields we would hear an occasional shot ring out from along the edges of wooded

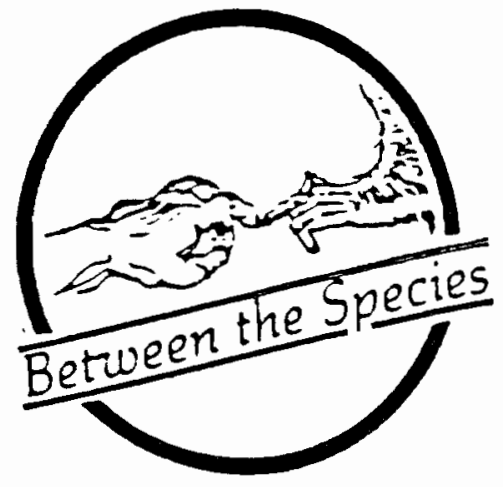

wetland. Both of us would pause and search in the direction of the hunt. Usually we would only see patches of flash-orange, but occasionally we would catch a glimpse of a fleeing deer. Almost as if choreographed we would both linger and watch for a time, then turn silently and continue our walk.

The sun was dropping quickly as we emerged from a clutch of pines into a grassy glade. Just as we cleared the last line of trees we caught a glimpse of a man with a young boy, maybe a hundred yards from us. The boy was looking down the sight of a shotgun that looked as if it would be longer than he was tall for at least a couple of more seasons. Not twenty yards from the barrel end of his firearm was a sturdy buck with 7 or 8 points of experience.

Everything suddenly stood still. Like a perfect little diorama, nothing moved, but everything stood out in perfect detail.

The deer looked directly at the boy, ears twitching. The boy was planted and locked onto the target. It seemed as if a full minute passed. Then, like the utterance of a powerful magic word, a twig snapped in the woods behind, spooking the deer. The buck's head snapped around in alarm, and he leapt into the air, his body propelling him away from both the hunters and the sound.

As the deer bounded into a heavily wooded marsh, our eyes turned back to the boy. He was lowering his

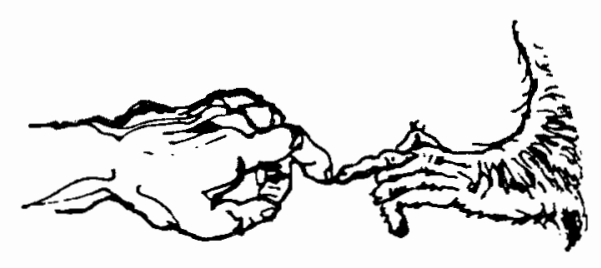


shotgun and his head seemed to descend as if pulled by the weight of the gun barrel.

With stunning speed and without warning. the man turned quickly, bringing his hand back and forward into the side of the boy's head, knocking him roughly to the ground. The gun fell from the boy's hand and it was all he could do to bring himself up to his hands and knees. As he did, the man began shrieking.

"You coward! What the hell is wrong with you? Why the hell didn't you shoot? Are you some kind of sissie? Get up sissie! Get up and pick up that goddamned gun. Now!" His words echoed across the field and against the trees behind us.

My jaws began to ache and my stomach knotted with hatred. I had to do something about this. I began to stride toward the man with purpose. As I moved forward I looked back over my shoulder to see if Dan too was moved to anger. I stopped suddenly.

Dan was no longer standing. He had crumpled to the ground, his chest resting on his knees, his forehead scraping the dirt. A muffled, keening sound escaped as he hugged himself, shifting from side to side.

"I'm sorry, Dad, I'm sorry, I can't. I can't. I just can't. I'm sorry. I'm sorry."

Something made me turn my head and look back at the scene that had triggered this reaction. As I did I saw the man haul the child up and shake him, his face inches from the boy's. I could no longer make out what he was saying, but I could hear the notes across the field. The boy was as limp as a rag doll and his head snapped back and forth to the rhythm of the man's anger. I was torn. I needed to do something to help this kid.

I looked at Dan, then back at the boy. The father began hauling him toward the woods. Dan was still racked with sobs. Quietly, I whispered after the boy, "hang in there kid." I knelt next to Dan and put my hand on his back.

The setting sun cast long, gently moving shadows. Sounds that had mysteriously disappeared during the brutal scene began to make themselves heard again. Crickets, the wind in the pines, a mourning dove. And as they grew, Dan's grief began to subside. We sat together in the glade for awhile. The sun subsided quickly now and left in its place a soothing purple glow. We stood up and made our way back to the car.

Without a word, we walked across the parking lot, footsteps crunching loudly on the loosely graded gravel. As we neared the car Dan suddenly veered right, striding purposefully toward a brown DNR dumpster sitting at the edge of the packed dirt. Gun in hand, he threw back the top. The hinges screeched and the top slammed the back of the can with a gunshot report. Dan stepped forward and without warning, dropped his shotgun in. Handfuls of shells he had just hours before crammed into his pockets followed the gun. When his pockets were empty he looked at me. He smiled sheepishly.

I looked down at the shotgun that Dan's father had given him. Stock beautifully carved and carefully polished, the metal barrel lovingly oiled-a powerful, tactile confirmation of his childhood. I looked up in question.

"Yes," Dan said, and his smile strengthened. I smiled back and began walking toward the trash can.

On the drive back we listened to Hank Williams Jr. sing about his dad, "and if you don't like Hank Williams, you can kiss my ass." I looked over at Dan. He grinned. "I'm never hunting again. And if I ever have a kid the only thing he's going to shoot is a camera.... and if my dad doesn't like it," he sang, "he can kiss my ass."

We both laughed. I turned to look out at the woods passing by. For the sake of the animals, but even more, for the sake of the boy in the woods, who would probably have a son of his own someday, I hoped he too would have the courage to throw away a brutal part of his childhood.

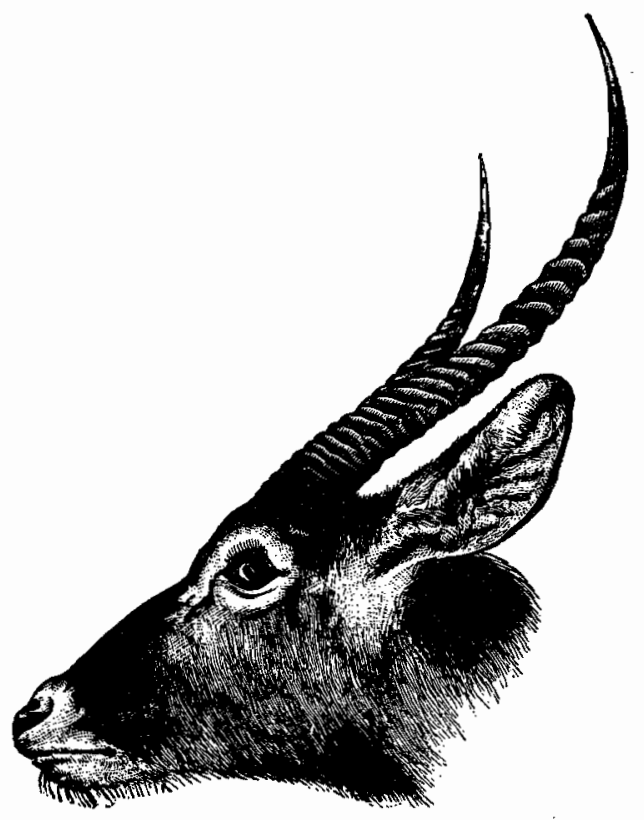

